Review

\title{
A Review of the Trade-Offs across Different Cocoa Production Systems in Ghana
}

\author{
Priscilla Wainaina ${ }^{1, *(D)}$, Peter A. Minang ${ }^{1}$, Lalisa Duguma ${ }^{1} \mathbb{D}$ and Kennedy Muthee ${ }^{1,2}(\mathbb{D})$ \\ 1 World Agroforestry (ICRAF), UN Avenue, Gigiri, P.O. Box 30677, Nairobi 00100, Kenya; \\ a.minang@cgiar.org (P.A.M.); 1.a.duguma@cgiar.org (L.D.); k.muthee@cgiar.org (K.M.) \\ 2 Department of Environmental Planning and Management, Kenyatta University, Nairobi 00100, Kenya \\ * Correspondence: p.wainaina@cgiar.org
}

check for updates

Citation: Wainaina, P.; Minang, P.A.; Duguma, L.; Muthee, K. A Review of the Trade-Offs across Different Cocoa Production Systems in Ghana. Sustainability 2021, 13, 10945. https:/ / doi.org/10.3390/su131910945

Academic Editor: Marco Lauteri

Received: 31 August 2021

Accepted: 27 September 2021

Published: 1 October 2021

Publisher's Note: MDPI stays neutral with regard to jurisdictional claims in published maps and institutional affiliations.

Copyright: (c) 2021 by the authors. Licensee MDPI, Basel, Switzerland. This article is an open access article distributed under the terms and conditions of the Creative Commons Attribution (CC BY) license (https:// creativecommons.org/licenses/by/ $4.0 /)$.

\begin{abstract}
Cocoa production is one of the leading causes of deforestation in West Africa. Agroforestry cocoa systems are increasingly promoted as a possible solution to deforestation. This study seeks to understand the trade-offs within agroforestry cocoa in full-sun and high-tech plantation cocoa systems in Ghana. It uses secondary data collected from an extensive literature search. The results established various trade-offs between cocoa yields and other provisioning services derived from the agroforestry services. While the cocoa yields in high-tech systems are almost thrice those in agroforestry systems, the total value of all the provisioning services is highest within the shaded systems. The economic value of per hectarage yield is estimated at USD 8140, USD 5320 and USD 5050 for shaded, full-sun and high-tech systems, respectively. Agroforestry systems also have higher ecosystem services compared to full-sun cocoa and high-tech cocoa systems. The high pesticide use in Ghana's high-tech cocoa systems is also strongly linked to water and soil pollution, as well as adverse effects on human health. The study concludes that different cocoa production systems in Ghana yield different types of ecosystem provision and are associated with externalities such as the effect of pesticides on soils, water and human health, thus there is a need for the careful consideration of the system from policy and practice perspectives.
\end{abstract}

Keywords: cocoa; Ghana; ecosystem services; production systems; trade-offs; agroforestry

\section{Introduction}

Cocoa is produced mainly in Africa, with Cote d'Ivoire and Ghana contributing to about three-quarters of the global cocoa production. Cocoa plantations occupy 1.7 million hectares in Ghana, and its contribution to total world cocoa is approximately $17 \%$, second only to Cote d'Ivoire (FAOSTAT database http:/ / www.fao.org/faostat/en/\#data (accessed on 24 October 2019)). It is a major source of revenue and a key contributor to the socioeconomic infrastructure in Ghana. The commodity directly employs about 800,000 farmers in Ghana, and a large proportion of their income (about $80 \%$ ) comes from cocoa production [1]. Similarly, in Cote d'Ivoire, cocoa employs approximately 1,000,000 farmers and constitutes about $90 \%$ of their income [1]. Even though cocoa farming is one of Ghana's dominant land-use activities, it is characterized by relatively small landholdings that range from 0.4 to 4 hectares [2]. Cocoa plays a vital role in the conservation of forests and their biodiversity in Ghana, both negatively and positively. On the one hand, cocoa is a significant contributor to deforestation owing to forest conversion for agriculture [3]. On the other hand, shaded cocoa provides a valuable secondary habitat for forest fauna and flora in agricultural landscapes [4].

The global demand for cocoa has grown over the years, with an estimated growth rate of $1 \%$ annually [5]. It is predicted that by $2020-2025,1,000,000$ additional tonnes of cocoa will be required to meet the growing demand. There is, therefore, a high risk of a shortage or increase in cocoa prices, hence an urgent need to increase production in the long term. In recent decades, the increase in cocoa production in Africa was achieved through increasing 
the land under cultivation and was a significant driver of deforestation and poverty [6]. According to FAOSTAT data (FAOSTAT database http: / / www.fao.org/faostat/en/\#data (accessed on 24 October 2019)), the area of cocoa plantations in Ghana increased from 730,000 ha to approximately 1.69 million ha between 1987 and 2017. At the same time, from 2001 to 2018, Ghana lost 1.09 Mha of tree cover, equivalent to a $16 \%$ decrease in tree cover since 2000, and produced $291 \mathrm{Mt}$ of $\mathrm{CO}_{2}$ emissions (Global Forest Watch https: / / www.globalforestwatch.org/ (accessed on 12 November 2019)). Similarly, from 2001 to 2018, Cote d'Ivoire, the largest global cocoa producer, lost 2.78 million ha of tree cover, equivalent to a $19 \%$ decrease in tree cover since 2000 , resulting in 730 million tonnes (Mt) of $\mathrm{CO}_{2}$ emissions (Global Forest Watch https: / / www.globalforestwatch.org / (accessed on 12 November 2019)). To reduce further deforestation, an increase in yield is inevitable, but there are various discussions on how to achieve the rise in yields sustainably.

Following the Boserupian theory, the intensification through high input use is suggested as an avenue to increase production through sparing land as opposed to extensive cocoa cultivation $[5,7,8]$. At a global level, technology-driven intensification is an effective land-saving measure, although deforestation in specific regions is likely to continue. The yield-enhancing effect might lead to more forest encroachment under some conditions. For example, market-driven intensification is often a significant cause of land expansion and deforestation, especially for export commodities such as cocoa in times of high prices [9]. Similarly, deforestation is likely to occur without forest conservation measures, such as the direct control of cropland expansion into forests or incentives to prevent and possibly reduce cropland expansion [10]. According to [7], intensive cocoa monocultures are increasing in West Africa owing to several reasons: technological progress with plant hybrids which are more high yielding; farmers' negative perceptions of ecological services in relation to hybrids; legislation excluding smallholders from the legal timber market; the recent expansion of the timber industry; and the migratory phenomenon where most migrants in West African countries seek quicker returns and are a major cause of deforestation.

Sustainable intensification, a key component of climate-smart agriculture, is also increasingly being promoted within cocoa farms as a strategy to minimize further deforestation. Climate-smart agriculture (CSA) aims to meet the triple challenge of raising agricultural productivity and farm incomes, enhancing adaptation and resilience to climate change and reducing greenhouse gas emissions from agriculture $[10,11]$. In addition to achieving the three objectives of CSA, agroforestry (AF) can directly benefit forest conservation. Thus, agroforestry systems are increasingly viewed as sustainable and environmentally preferable to other forms of agricultural activities in tropical forest regions [10]. Agroforestry systems can lead to an increased output per unit of land since farmers have multiple income streams on the same piece of land, resulting in an increase in income and a reduction in the demand for land, thereby reducing deforestation [6]. They also prevent deforestation by reducing the harvest from natural forests of timber, fuelwood, charcoal, fodder and other products that agroforestry trees provide [6]. In addition, agroforestry systems can offer other benefits, including timber, wood fuel, non-timber food products (NTFPs), and ecological benefits (e.g., biological pest control, maintaining biodiversity, soil erosion control, pollination services, and carbon sequestration, among others [12].

Cocoa farmers in Ghana practice different production systems, including high-tech plantations (highly intensified production systems), full-sun cocoa and shaded cocoa (agroforestry) production systems. These production systems play different roles in sustainable cocoa production. Trade-offs exist among these cocoa production systems in terms of provisioning services, inputs, ecosystem services and negative externalities. Hence, the need for an inclusive study that compares the advantages and disadvantages (trade-offs) across the different cocoa production systems [7,8]. Some studies $[5,13,14]$ highlighted some of the trade-offs between agroforestry systems and the intensification practices among cocoa farmers. However, a comprehensive study focusing on the quantification and valuation of these trade-offs could be influential for policy decisions. Thus, this paper applies secondary data obtained through the comprehensive literature search to identify and quantify the 
trade-offs that exist among the different cocoa production systems in Ghana. We also value some of the ecosystem services, as well as discuss the policy implications.

\section{Cocoa Production Systems in Ghana}

Over the last three decades, cocoa produced in Ghana increased significantly; the total cocoa produced in 2017 was almost six times the amount produced in 1987 (Data source: FAOSTAT Database). As shown in Figure 1, the trend for the area harvested mirrors the total production trend, implying that the increase in cocoa produced is mainly due to an increase in the area under production, as opposed to an increase in yield. The area of cocoa plantations in Ghana has more than doubled over the last 30 years. However, the average cocoa yields in these West African countries, including Ghana, remain relatively low due to low input use, inadequate maintenance and pest and disease control, little or no fertilizer use, and the old age of cocoa farms [15].

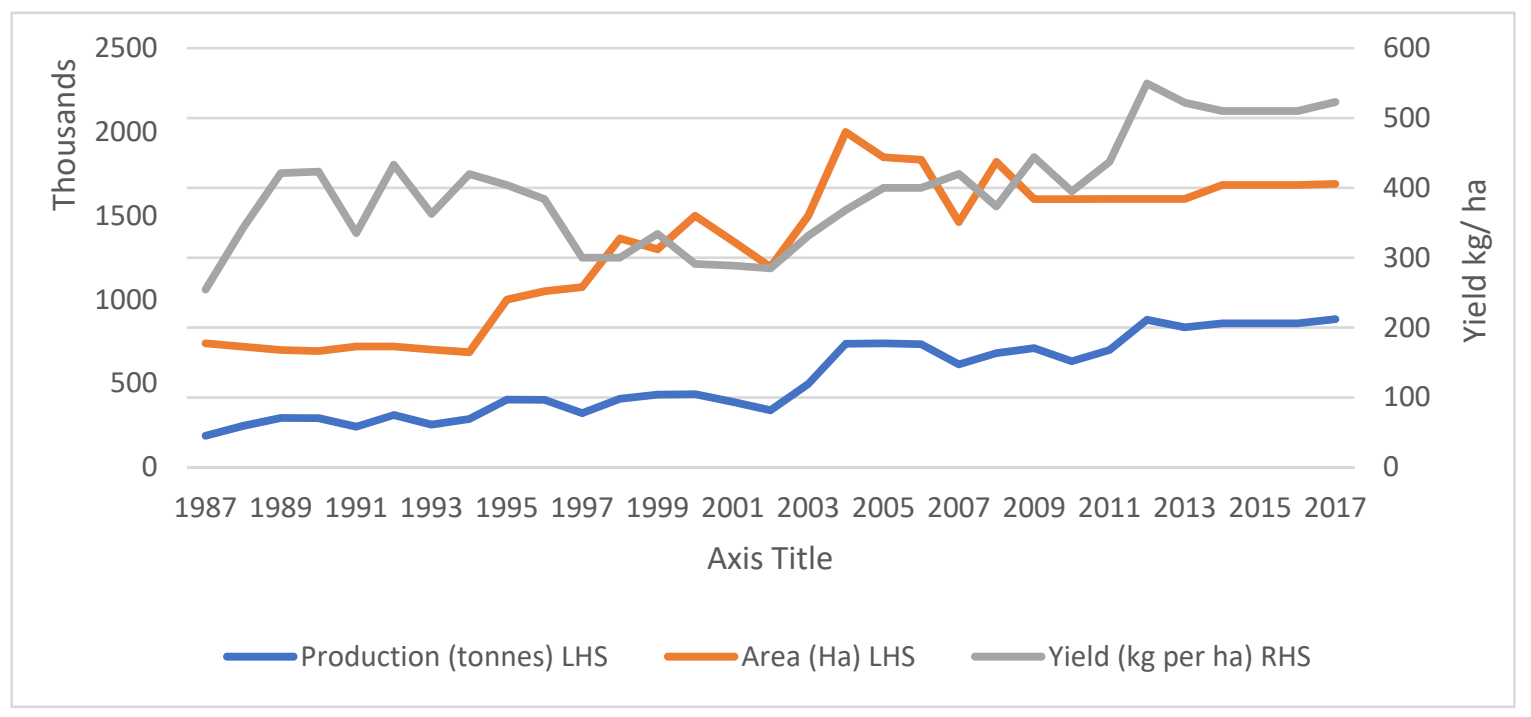

Figure 1. Production, yield, and area harvested trends for cocoa in Ghana.

In Ghana, approximately $50 \%$ of the cocoa farming area is under mild shade, while about $10 \%$ is managed under no shade. Overall, there was a decrease in shaded cocoa in recent decades in West Africa [7,16]. Shaded cocoa was defined as having more than 50\% of its tree canopy above the cocoa canopy, and full-sun cocoa was defined as any farm with fewer than 13 shade trees per ha [17]. Most of the time, cocoa was inter-cropped with food crops such as plantain within full-sun production systems. High-tech (plantation) cocoa production systems, on the other hand, were the most highly intensified cocoa production systems, and it involves high input use and, in most cases, without any shade $[8,18]$.

\section{Data}

This study used secondary data sourced from different publications within and outside the study areas for some economic/ecosystem services. Although we did not conduct a formal systematic review, we conducted a comprehensive literature search to include studies illustrating the costs, benefits and externalities within the cocoa production systems to provide a balanced assessment. The data were sourced from grey and peer-reviewed literature by using Google Scholar, Web of Science, ResearchGate, to search for different keywords. The search was conducted in October 2019 for studies conducted between 1990 and 2019. The key search terms were: "Cocoa production system" and "Ecosystem services" and "Ghana"; "Cocoa" and "Ecosystem services" and "Ghana"; "Cocoa" and "Agroforestry" and "Ecosystem services" and "Ghana"; "Cocoa" and "Shade" and "Ecosystem services" and "Ghana." We further conducted searches for the specific ecosystem services shown in Table 1. We filtered down the papers from the search outputs focusing 
on the specific economic or ecosystem services outlined in Table 1. The review process included journal articles, working papers, technical reports, theses and book chapters.

Table 1. Number of publications reviewed.

\begin{tabular}{|c|c|c|c|c|c|c|}
\hline Economic/Ecosystem Services & $\begin{array}{l}\text { Number of } \\
\text { Articles } \\
\text { Reviewed }\end{array}$ & $\begin{array}{l}\text { Journal } \\
\text { Articles }\end{array}$ & Theses & $\begin{array}{l}\text { Working/ } \\
\text { Conference } \\
\text { Papers }\end{array}$ & Reports & $\begin{array}{l}\text { Book } \\
\text { Chapters }\end{array}$ \\
\hline Carbon stocks in Ghana's cocoa systems & 8 & 6 & & & 1 & 1 \\
\hline Soil nutrient stocks in Ghana's cocoa systems & 4 & 3 & & & & 1 \\
\hline Biodiversity in Ghana's cocoa systems & 5 & 3 & & & 1 & 1 \\
\hline Health effects from pesticides exposure in Ghana & 3 & 2 & 1 & & & \\
\hline $\begin{array}{l}\text { Agricultural and food outputs in cocoa production } \\
\text { systems in Ghana }\end{array}$ & 11 & 8 & & & 2 & 1 \\
\hline Input use in Ghana's cocoa production & 7 & 4 & 1 & 1 & 1 & \\
\hline $\begin{array}{l}\text { Biological pest control in shaded cocoa (Outside } \\
\text { Ghana) }\end{array}$ & 1 & 1 & & & & \\
\hline Pollination (outside Ghana 1) & 2 & 1 & & & 1 & \\
\hline $\begin{array}{l}\text { Pesticides emissions to water and soil during cocoa } \\
\text { production in Ghana }\end{array}$ & 4 & 4 & & & & \\
\hline $\begin{array}{l}\text { Greenhouse gases emissions (two studies were } \\
\text { outside Ghana) }\end{array}$ & 3 & 2 & & & & \\
\hline Total & 48 & 34 & 2 & 1 & 6 & 4 \\
\hline
\end{tabular}

As shown in Table 1, the economic or ecosystem services for which we reviewed substantially more articles included agricultural and food outputs (11), carbon stocks within the cocoa production systems (8), and input use in Ghana's cocoa production (7). On the other hand, few relevant publications were found on some ecosystem services, and only one or two publications were reviewed. These included pollination services and biological pest control. In fact, for biological pest control, we did not find any publication specific for Ghana and the data were sourced from outside Ghana.

Since the data were sourced from secondary sources, they had limitations compared to using primary data. First, the data were sourced from various studies using multiple methodologies and conducted in different locations within Ghana; some values may change depending on the approach by the studies. Second, in quantifying and valuing some of the ecosystem services, we made assumptions which are explained in the results section; these values may change when these assumptions fail to hold. However, we made efforts to include a rich set of studies that provided a substantive representation of the cocoa production systems in Ghana.

\section{Results}

This section presents the results from comparing the outputs, inputs, ecosystem services, and externalities among the different cocoa production practices in Ghana. We discuss the various trade-offs that exist among the production systems.

\subsection{Trade-Offs in Provisioning Services}

Table 2 presents the various agricultural and food outputs from three cocoa production systems: agroforestry systems, full-sun cocoa systems and high-tech systems (cocoa grown under highly intensive systems with extensive use of external inputs). The yield quantities are derived from various studies conducted within Ghana and are valued at the current producer price in Ghana. These studies derived their yield estimates using various methods, including long-term yield regression analyses for the shaded and full-sun cocoa systems, e.g., [2,8,19], household surveys, e.g. [20], and field estimates, e.g., [21]. The cocoa yields were lowest in the shaded cocoa (approximately $366 \mathrm{kgs}$ per ha) compared to full-sun cocoa (451 kgs per ha) and high-tech cocoa (1041 kgs per ha). These yield levels compare favourably with the yield levels reported elsewhere. For example, [22] reported a yield of 
$540 \mathrm{kgs}$ per ha and [2] reported a yield of 450-539 kgs per ha. The cocoa is valued at USD 4.85 per $\mathrm{kg}$, which is the purchasing power parity (PPP) equivalent of the 2018 cocoa price issued by the Ghana Cocoa Board (COCOBOD) (GHS 7.42).

Table 2. Agricultural and food outputs for various cocoa systems in Ghana (per hectare per year).

\begin{tabular}{|c|c|c|c|c|}
\hline System & Service & Amount & Value USD per ha & References and Comments \\
\hline \multirow{15}{*}{ Moderate shade cocoa } & Cocoa $(\mathrm{kg})$ & 280 & & [8] \\
\hline & & 403 & & [19] \\
\hline & & 321 & & [21] \\
\hline & & 380 & & [25] \\
\hline & & $448 *$ & & {$[20]$} \\
\hline & Average cocoa & 366.4 & 1777 & Valued at USD 4.85 per $\mathrm{kg}^{* *}$ \\
\hline & Plantain $(k g)$ & 3500 & 3130 & [8] \\
\hline & Fruit tree products $(\mathrm{kg})$ & 348.9 & 339.73 & [23] \\
\hline & Other food crops & & 2821.65 & [23] \\
\hline & Timber $\left(\mathrm{m}^{3}\right)$ & 1.04 & & [19] \\
\hline & & 0.48 & & [8] \\
\hline & & 0.23 & & [24] \\
\hline & & 0.85 & & [2] \\
\hline & Average timber & 0.65 & 70.5 & \\
\hline & Total & & 8139 & \\
\hline \multirow{7}{*}{$\begin{array}{c}\text { Unshaded } \\
\text { (Full-sun)/low-shade } \\
\text { system }\end{array}$} & Cocoa $(\mathrm{kg})$ & 519 & & [19] \\
\hline & & 318 & & [24] \\
\hline & & 517 * & & {$[20]$} \\
\hline & Average & 451.3 & 2189 & Valued at USD 4.85 per $\mathrm{kg}^{* *}$ \\
\hline & Plantain (kg) & 3500 & 3130 & [8] \\
\hline & Litter & 200 & & \\
\hline & Total & & 5319 & \\
\hline \multirow{5}{*}{ High tech } & Cocoa $(\mathrm{kg})$ & 1235 & & [8] \\
\hline & & 1053 & & [19] \\
\hline & & 927 & & [24] \\
\hline & & 949 & & [2] \\
\hline & Average cocoa & 1041 & 5049 & \\
\hline
\end{tabular}

* These figures from [20] are averages from dry, mid and wet cocoa growing regions in Ghana. ${ }^{* *}$ Cocoa pricing was at GHS 7.42 per kg, equivalent to USD 4.85 when applying the 2018 Worldbank purchasing power parity (PPP conversion factor): https:/ / www.reuters.com/ article/ghana-cocoa/update-2-ghana-sets-2016-17-season-farmgate-cocoa-price-at-1914-per-tonne-idUSL8N1C70DK (accessed on 21 March 2019).

However, for the shaded cocoa systems, in addition to cocoa, there are additional products, including plantain, timber, fruits and other food products. Since agroforestry cocoa is often combined with timber production, it is assumed that moderate shade agroforestry contains, in addition to cocoa, 30 fruit trees and approximately 10 timber trees per hectare [23]. This provides an average timber yield of $0.65 \mathrm{M}^{3} /$ ha based on the data from $[2,8,19,24]$. We also included the value of plantain within the shaded cocoa systems, valued at USD 3130 per ha, as well as other food products valued at USD 2822 per ha $[8,23]$. Similarly, the full-sun production systems included food crops within the systems, mostly plantain. Cumulatively, the total value of all the products was highest for the cocoa agroforestry systems (USD 8139 per ha). The total product value was almost equal for the high-tech cocoa system (USD 5049 per ha) and the full-sun cocoa system (approximately USD 5319 per ha). Figure 2 also presents a comparison of the agricultural and food outputs from the three cocoa production systems in Ghana. 


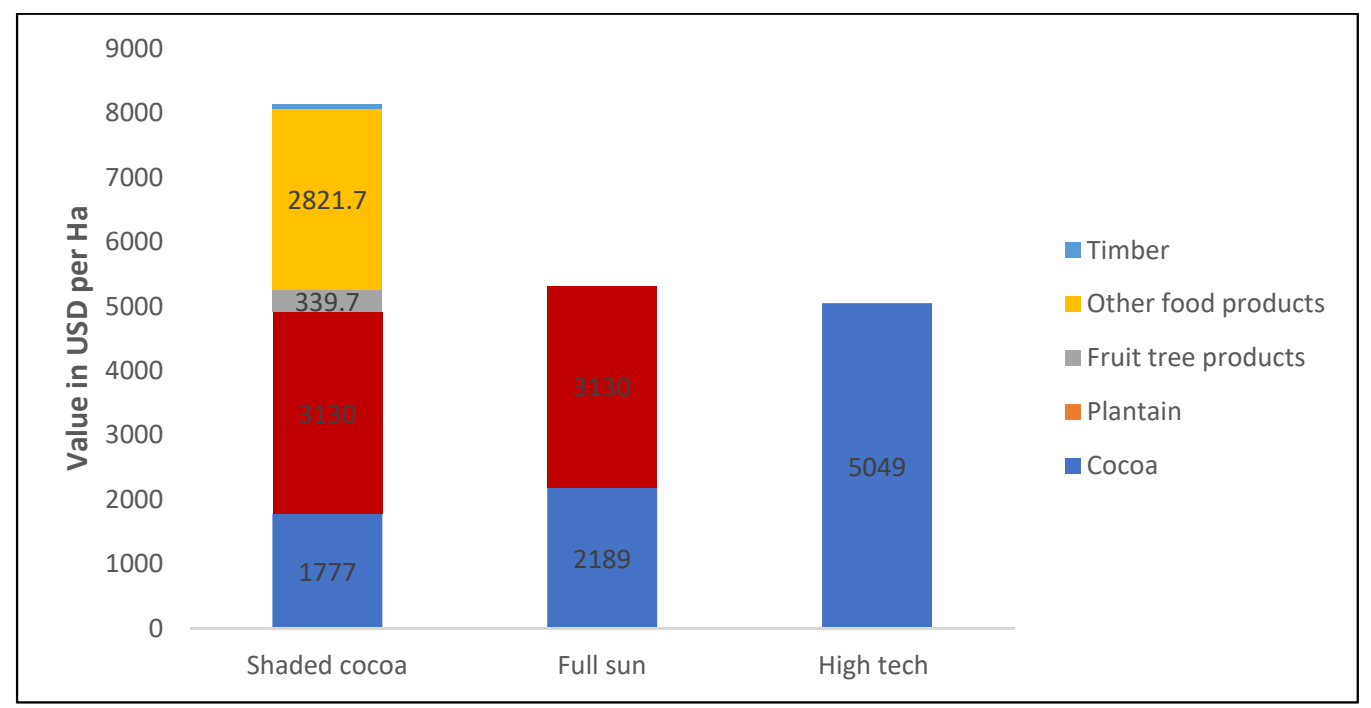

Figure 2. Total output value across different cocoa production systems.

\subsection{Inputs within Cocoa Production Systems in Ghana}

Table 3 shows the inputs used in the production of cocoa in Ghana. We compare three cocoa farming systems: shaded cocoa, full-sun cocoa and high-tech cocoa. The quantities are input from studies across Ghana and then valued at the current market price. For all the three cocoa production systems, labour constitutes the most significant component of input cost, estimated at USD 1494 per ha for shaded cocoa, USD 1565 per ha for full-sun cocoa, and about USD 2359 per ha for high-tech cocoa. The use of fertilizer and agrochemicals was substantially low for agroforestry cocoa systems, estimated at USD 18 and USD 21 per ha, respectively, but, as expected, was highest for high-tech cocoa systems, estimated at USD 551 per ha and USD 165 per ha, respectively. Cumulatively, the total costs were highest for the high-tech cocoa system (approximately USD 3427 per ha), followed by the full-sun cocoa system (USD 1996 per ha) and were lowest for the shaded cocoa systems (USD 1885 per ha). Figure 3 also presents a comparison of the input costs from the three cocoa production systems in Ghana.

Table 3. Input use in cocoa production systems.

\begin{tabular}{|c|c|c|c|c|c|}
\hline System & Inputs & Unit & Quantity & Value (USD per ha) & References \\
\hline \multirow{19}{*}{ Moderate shaded coffee } & Fertilizer & $\mathrm{kg} \mathrm{ha}^{-1}$ & 144 & & [25] \\
\hline & & $\mathrm{kg} \mathrm{ha}^{-1}$ & 37 * & & [20] \\
\hline & average & & $90.5^{* *}$ & 35.30 & \\
\hline & & & & 0.00 & [8] \\
\hline & Average fertilizer cost & & & 17.65 & \\
\hline & Herbicides & Litres ha ${ }^{-1}$ & 1.85 & 7.98 & \\
\hline & Fungicides & Grams ha $^{-1}$ & 171.75 & 2.53 & \\
\hline & Pesticides & Litres ha ${ }^{-1}$ & 2.22 & & [25] \\
\hline & Pesticides & Litres ha ${ }^{-1}$ & 4.4 * & & [20] \\
\hline & Average pesticides & & $3.31^{* * *}$ & 10.98 & \\
\hline & Total agrochemicals & & & 21.49 & \\
\hline & Agrochemicals & & & 21.12 & [19] \\
\hline & Average agrochemicals cost & & & 21.31 & \\
\hline & Labour & Person day ha ${ }^{-1}$ & 206 & 908.46 & [26] \\
\hline & & & & 2250.58 & [8] \\
\hline & & & & 1321.92 & [24] \\
\hline & Average labour cost & & & 1493.65 & \\
\hline & Other inputs & & & 351.95 & [23] \\
\hline & Total input cost & & & 1884.56 & \\
\hline
\end{tabular}


Table 3. Cont.

\begin{tabular}{|c|c|c|c|c|c|}
\hline System & Inputs & Unit & Quantity & Value (USD per ha) & References \\
\hline \multirow{15}{*}{$\begin{array}{l}\text { Full-sun/low-shade } \\
\text { cocoa systems }\end{array}$} & Fertilizer & $\mathrm{kg} \mathrm{ha}^{-1}$ & 215.25 & & [25] \\
\hline & & & $50 *$ & & [20] \\
\hline & & Average & 132.63 & 51.72 & \\
\hline & Herbicides & Litres ha ${ }^{-1}$ & 2.28 & 9.84 & \\
\hline & Fungicides & Grams ha $^{-1}$ & 213 & 3.13 & [25] \\
\hline & Pesticides & Litres ha ${ }^{-1}$ & 2.35 & & \\
\hline & & Litres ha ${ }^{-1}$ & $6.07 *$ & & [20] \\
\hline & Average & & 4.21 & 13.93 & \\
\hline & Total agrochemicals cost & & & 26.9 & \\
\hline & Labour & Person day $\mathrm{ha}^{-1}$ & 217 & 956.97 & [26] \\
\hline & & & & 2385.78 & [19] \\
\hline & & & & 1353.98 & {$[24]$} \\
\hline & Average labour cost & & & 1565.58 & \\
\hline & Other inputs & & & 351.95 & [23] \\
\hline & Total input cost & & & 1996.35 & \\
\hline \multirow{5}{*}{ High-techcocoa systems } & Fertilizer & $\mathrm{kg} \mathrm{ha}^{-1}$ & 371 & 551 & [8] \\
\hline & Agrochemicals & & & 164.80 & [23] \\
\hline & Labour & & & 2358.78 & [19] \\
\hline & Other inputs & & & 351.95 & [23] \\
\hline & Total input cost & & & 3426.53 & \\
\hline
\end{tabular}

* These figures from [20] are averages from dry, mid and wet cocoa growing regions in Ghana. ${ }^{* *}$ fertilizer prices are valued at USD 0.39 per kg. Average annual price in Ghana 2017/2018, source https:/ / africafertilizer.org/national/ (accessed on 5 June 2019). ${ }^{* * *}$ We value pesticides at USD 3.31 per litre, herbicides at USD 4.32 per litre, and fungicides at USD 0.74 per $50 \mathrm{~g}$ source [27].

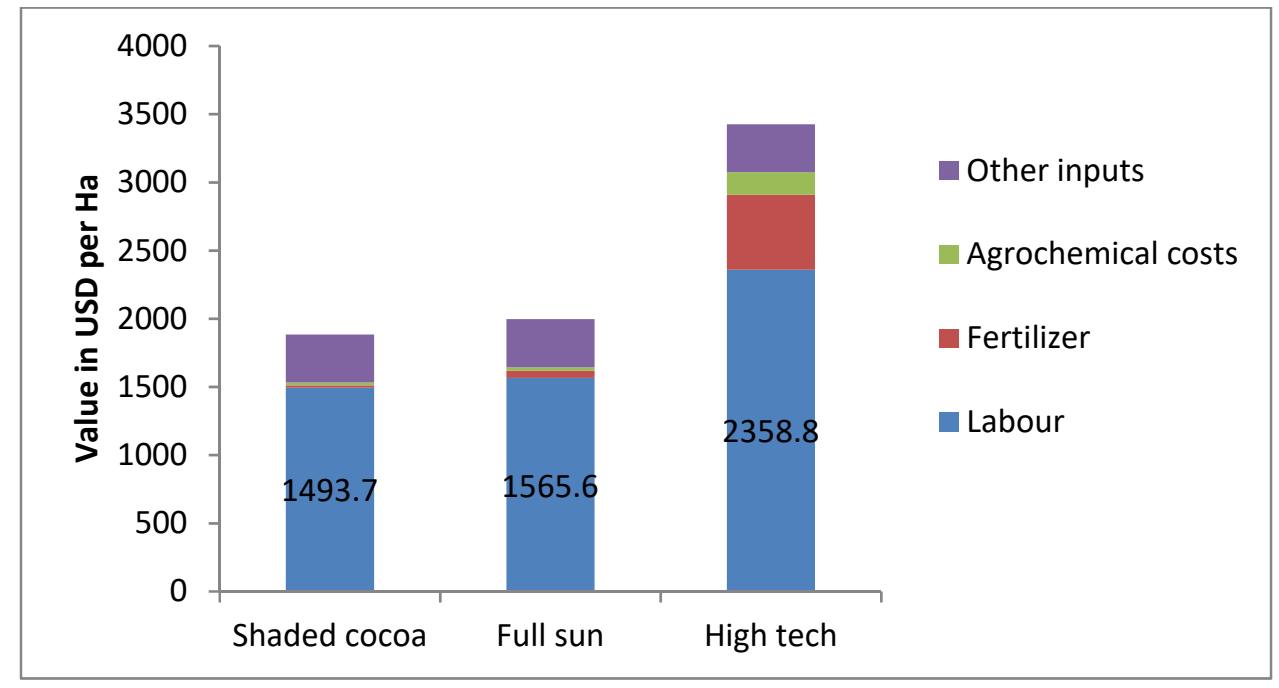

Figure 3. A comparison of input costs in cocoa production by the cocoa system.

\subsection{Ecosystems Services within Cocoa Production Systems in Ghana}

In addition to the provisioning services within the production systems, we discuss the ecosystem services generated by the different cocoa production systems, including carbon sequestration, biological disease control, improved biodiversity, and pollination services, among others.

\subsubsection{Biodiversity in Cocoa Agroforestry Systems and Full Sun Cocoa}

Agroforestry is shown to improve biodiversity conservation. According to [28], agroforestry plays five major roles in conserving biodiversity: (1) it provides habitats for species that can tolerate a certain level of disturbance; (2) helps preserve the germplasms of sensitive species; (3) helps to reduce the rates of conversion of natural habitats; (4) provides connectivity by creating corridors between habitat remnants which may support the in- 
tegrity of these remnants and the conservation of area-sensitive floral and faunal species; and (5) helps to conserve biological diversity by providing other ecosystem services, thereby reducing the degradation and loss of surrounding habitat.

Table 4 presents a comparison of biodiversity between agroforestry cocoa systems and full-sun cocoa systems. A comparison by [29] shows that shaded cocoa systems have higher vegetation species (60\% of those in forest systems) compared to the full-sun systems $(8 \%)$. The bird species were also more abundant $(77 \%)$ in the shaded systems compared to in full-sun systems (32\%). More fruit-feeding butterflies (61\%) were found in the shaded systems compared to the full-sun systems (41\%). Similarly, [21] found that the shaded cocoa systems had a higher number of tree species ( $15 \%$ of those found in forests) while the full-sun cocoa systems had only $8 \%$. The study of [30] also reported a higher vegetation diversity index in shaded cocoa systems, as indicated by the Shannon- $\mathrm{H}$ index of 1.34 compared to an index of 1.3 in full-sun systems. This highlighted the positive effect of agroforestry systems in maintaining biodiversity.

Table 4. Biodiversity in cocoa agroforestry systems and full-sun cocoa.

\begin{tabular}{|c|c|c|c|}
\hline System & $\%$ Compared to Natural Forest & Biodiversity Index & References and Comments \\
\hline \multirow[t]{2}{*}{ Forest } & & & $\begin{array}{l}\text { [21] } 170 \text { tree species were identified } \\
\text { in forest systems. }\end{array}$ \\
\hline & & 2.67 (Shannon-Weiner-birds) & {$[31]$} \\
\hline \multirow[t]{4}{*}{ Moderate shade } & $\begin{array}{l}15 \% \text { of the number of tree } \\
\text { species }\end{array}$ & & [21] \\
\hline & $60 \%$ of vegetation species & & {$[29]$} \\
\hline & & 1.34 (Shannon H-vegetation) & $\begin{array}{l}\text { [30] } 40 \text { tree species were identified } \\
\text { in moderate shade systems. }\end{array}$ \\
\hline & $77 \%$ bird species & & [29] \\
\hline \multirow[t]{4}{*}{ Mature agroforests } & $50 \%$ species richness & & [32] \\
\hline & $50 \%$ bird species richness & & [31] \\
\hline & & 1.47 (Shannon-Weiner-birds) & [31] \\
\hline & $61 \%$ fruit-feeding butterflies & & [29] \\
\hline \multirow[t]{5}{*}{ Full sun } & & 1.3 (Shannon H) & {$[30]$} \\
\hline & $8 \%$ number of tree species & & $\begin{array}{l}\text { [21] } 14 \text { tree species were identified } \\
\text { in the full-sun systems. }\end{array}$ \\
\hline & $8 \%$ vegetation species & & {$[29]$} \\
\hline & $32 \%$ bird species & & [29] \\
\hline & $41 \%$ fruit-feeding butterflies & & [29] \\
\hline
\end{tabular}

\subsubsection{Carbon Storage between Different Production Systems}

Agroforestry systems received increased attention as potentially cost-effective options for climate change mitigation due to their importance in carbon storage and sequestration while also maintaining livelihoods. Table 5 presents the above-ground biomass carbon stock and the soil carbon stock in tonnes per hectare. The carbon stock levels were sourced from different studies conducted in cocoa production systems in Ghana and valued at the current market and social price of carbon. For shaded cocoa, the above-ground carbon stock reported by various studies ranged from 15.8 tonnes $C$ ha $^{-1}$ to 25.8 tonnes $C$ ha $^{-1}$. For unshaded cocoa, the range was from 17.8 to 39.2 tonnes $C \mathrm{Ca}^{-1}$. However, the reported soil carbon stock levels were higher within the shaded cocoa systems, ranging from 34.8 to 83.7 tonnes $\mathrm{C} \mathrm{ha}^{-1}$ for shaded cocoa systems and from 33.3 to 99.8 tonnes $\mathrm{C} \mathrm{ha}{ }^{-1}$ for unshaded cocoa systems. For perennial cropping systems, such as coffee and cocoa, adding shade trees may not have the same potential for soil carbon sequestration as in annual cropping systems. This may be because the litter produced by shade trees in the perennial cropping systems might not significantly increase carbon inputs to levels above those of the perennial crops alone [33]. 
Table 5. Carbon stocks for cocoa agroforestry and full-sun systems (Above ground and soil carbon stocks).

\begin{tabular}{|c|c|c|c|c|}
\hline Service & System & $\begin{array}{l}\text { Quantity } \\
\text { Tonnes C ha }\end{array}$ & $\begin{array}{l}\text { Value } \\
\text { USD ha }\end{array}$ & References \\
\hline \multirow{10}{*}{ Biomass C stock } & \multirow{3}{*}{ Moderate shade } & 23.74 & & [30] \\
\hline & & 15.77 & & [35] \\
\hline & & 25.8 & & [34] \\
\hline & \multirow[t]{2}{*}{ Average } & 21.77 & $519-3276$ & \\
\hline & & 17.8 & & [34] \\
\hline & \multirow{4}{*}{ Full sun } & 28.16 & & [17] \\
\hline & & 39.2 & & [21] \\
\hline & & 16.9 & & [30] \\
\hline & & 23.9 & & [29] \\
\hline & Average & 25.19 & $601-3791$ & \\
\hline \multirow{9}{*}{ Soil C stock } & \multirow{4}{*}{ Moderate shaded } & 83.7 & & [34] \\
\hline & & 34.8 & & [36] \\
\hline & & 40.7 & & [37] \\
\hline & & 51.4 & & [29] \\
\hline & \multirow[t]{2}{*}{ Average } & 52.65 & $1256-7922$ & \\
\hline & & 99.8 & & [34] \\
\hline & \multirow[t]{2}{*}{ Full sun } & 43.2 & & [17] \\
\hline & & 33.3 & & [29] \\
\hline & Average & 58.77 & $1402-8843$ & \\
\hline
\end{tabular}

(USD 41 per tonne of CO2e). Conversion rate from tonnes $\mathrm{C}$ to tonnes $\mathrm{CO} 2 \mathrm{e}$ is 3.67.

On average, the level of above-ground carbon stocks was slightly higher for the unshaded cocoa system ( 25 tonnes $\mathrm{C} \mathrm{ha}^{-1}$ ), valued at approximately USD 519-3276 per ha, compared to the shaded systems (22 tonnes $\mathrm{C} \mathrm{ha}^{-1}$ ), valued at USD 601-3791 per ha. Similarly, the average level of below-ground carbon stocks was higher for the unshaded cocoa systems: approximately 58 tonnes $\mathrm{C} \mathrm{ha}^{-1}$ valued at USD 1402-8843 per ha compared to the shaded (53 tonnes $\mathrm{C} \mathrm{ha}^{-1}$ ) valued at USD 1256-7922 per ha. However, although the averages were higher for unshaded cocoa systems, a comparison within the same area using the same methods of measuring carbon stocks showed that the above carbon stocks were higher within the shaded systems compared to the unshaded systems $[30,34]$. Similarly, for below carbon stocks, a comparison within the same study area, for example in [29], showed higher soil carbon stocks within the shaded systems (51.4 tonnes C per ha) compared to the full-sun systems (33.3 tonnes $C$ per ha).

\subsubsection{Soil Fertility within Different Cocoa Systems}

Table 6 presents the soil macronutrient levels, mainly carbon $(C)$, nitrogen $(\mathrm{N})$, Potassium $(\mathrm{K})$ and Phosphorous (P), for shaded and unshaded cocoa systems. Different sources report soil nutrients using different parameters, some as $\mathrm{kg}$ of the nutrient per ha, some as percentages, and some as ug/g. Generally, the soil nutrient levels are higher within the shaded cocoa systems compared to the unshaded systems. For example, [38] compared soil nutrient levels (C, P, K and N) between shaded cocoa and unshaded cocoa in topsoils in Ghana. The soils from shaded cocoa areas had, on average, significantly more C (by $20 \%$ ) and more N (by 16\%) compared to the unshaded cocoa soils. However, there were no significant differences in the total $\mathrm{P}$ and extractable $\mathrm{K}$ between soils in shaded cocoa systems and unshaded systems. A similar comparison by [29] shows a higher \% soil $\mathrm{N}$ in moderately shaded cocoa systems $(0.24 \%)$ compared to high-tech cocoa systems $(0.19 \%)$. Further still [29], Asase et al. (2008) reported substantially more available soil P stocks in shaded cocoa systems $(15.5 \mathrm{ug} / \mathrm{g})$ compared to high-tech systems $(9.9 \mathrm{ug} / \mathrm{g})$. This outlines the benefit of agroforestry systems in enhancing soil fertility. 
Table 6. Soil nutrient stock for shaded and unshaded cocoa production systems.

\begin{tabular}{llll}
\hline System & Service & Quantity (per ha) & References \\
\hline & Soil C & $21.3 \mathrm{~g} \mathrm{~kg}^{-1}$ & \\
& Soil N & $2.3 \mathrm{~g} \mathrm{~kg}^{-1}$ & [38] \\
& Available P & $0.24 \mathrm{~g} \mathrm{~kg}^{-1}$ & \\
Shaded cocoa/Moderate shade & Extractable K & $31 \mathrm{mg} \mathrm{kg}^{-1}$ & \\
& & & \\
& \% soil N & $0.24 \%$ & [29] \\
& Available P stock & $15.5 \mathrm{ug} / \mathrm{g}$ & \\
& Exchangeable K stock & $0.1 \mathrm{cmol} /(+)$ & \\
& Soil C & $18 \mathrm{~g} \mathrm{~kg}^{-1}$ & \\
& Soil N & $1.9 \mathrm{~g} \mathrm{~kg}^{-1}$ & \\
& Available P & $0.23 \mathrm{~g} \mathrm{~kg}$ & \\
& Extractable K & $30.5 \mathrm{mg} \mathrm{kg}$ & \\
High tech/No shade cocoa & \% soil N & $0.19 \%$ & \\
& Available P stock & $9.9 \mathrm{ug} / \mathrm{g}^{-1}$ & \\
\hline
\end{tabular}

\subsubsection{Biological Pest and Disease Control}

Agroforestry practices is also found to reduce the severity of diseases in Ghana's cocoa, particularly the cocoa swollen shoot virus disease (CSSVD). CSSVD affects cocoa plants at any development stage, and the only current treatment method, which is known to be effective at tackling this disease, is to fell infected trees. The number of cocoa trees infected with CSSVD in Ghana is estimated to be over 300 million, which has reduced the regular incomes for farmers, with entire crop fields being lost in some cases [39]. Agroforestry is found to reduce the incidences of CSSVD through decreasing pest species (diseases vectors) populations, as well as favouring natural pest predators which feed on the disease vectors [39].

We can estimate the value of biological pest control in the cocoa agroforestry systems in Ghana by applying the avoided loss approach. The economic value of biological pest control is equated to the value of the avoided loss attributable to biological pest control. The study in [40] estimated the value of avoided yield loss from biological pest control in Indonesian cocoa agroforestry systems to be $31 \%$. This avoided the loss in yield of $31 \%$, which was the loss prevented by biological agents (birds and bats) and may not necessarily be fully attributable to agroforestry. However, a richer variation in bird species (both forest and non-forest bird species) is reported in shaded cocoa systems compared to the unshaded systems [29]. Hence, biological pest control is expected to be higher in the shaded systems compared to the unshaded systems.

\subsubsection{Pollination}

Following the FAO Array for the economic valuation of the contribution of insect pollination to agriculture and its impact on welfare (http:/ / www.fao.org/fileadmin/user upload/pollination/docs/POLLINATION_VALUE_ARRAY.xls (accessed on 14 October 2019)), cocoa is one of the crops for which pollination is classified as essential, with a pollinator dependency factor of 0.95 . The pollinator dependency factor is an indicator of the pollination contribution to the production value per hectare. This factor is influenced by the variation in the richness and abundance of pollinators in the cocoa fields. Thus, pollination is expected to be higher within the shaded cocoa systems compared to the monoculture systems since insect and pollinator biodiversity is higher within agroforestry systems and forest systems [41]. Additionally, a study in Ghana by [42] showed that the cocoa intercrop could enhance cocoa pollination. 


\subsection{Negative Externalities within Cocoa Production in Ghana}

\subsubsection{Water and Soil Emissions from Pesticides Used in the Production of Cocoa}

Insects, pests and diseases pose a significant challenge for cocoa production in Ghana, and negatively affect the economy of the country. To reduce the incidence and severity of insect pests and diseases, a large number of pesticides, including organochlorines, are usually applied on farms [43]. The regular use of chemicals and pesticides was associated with adverse environmental and human health effects [44]. Several studies assessed the levels of pesticide residues in soils and drinking water sources from cocoa farms in Ghana [43-46]. The presence of pesticides in the water samples could be traced to direct overspray, the atmospheric transport of volatilized pesticides or wind drift, direct spillage, pesticide misuse by farmers, as well as leaching and runoff from application fields and the surrounding areas during and after pesticide applications. From these studies, although most of the pesticide residues recorded in water were below the World Health Organization Maximum Residue levels (WHO MRLs) for drinking water, some pesticides exceeded the WHO MRLs at some sampled sites.

The pesticide residues in the soil also pose a danger to soil organisms and surrounding water bodies through runoff and leaching. Additionally, there is the likelihood of the translocation of pesticide residues from the soil into the cocoa beans and other intercrops through the root system, thus risking the health of the consumers [43]. The studies in $[47,48]$ applied the life cycle assessment (LCA) approach to capture environmental and health effects in the production and processing of cocoa, as well as the effects of the pesticides in the cocoa food chain in Ghana. They assessed the acidification and eutrophication levels, as well as the freshwater aquatic and terrestrial toxicity levels, shown in Table 7. Eutrophication, or nitrification, is a measure of the over-fertilization of soils and contamination of water bodies with nutrients. In waters, it causes excessive algae growth and the negative modification of the aquatic ecosystems resulting in the oxygen depletion and death of certain aquatic species. In soils, on the other hand, it promotes monocultures and the loss of biodiversity [48].

Table 7. Environmental impact from production and processing of cocoa in Ghana (1 tonne of cocoa beans).

\begin{tabular}{lrr}
\hline \multicolumn{1}{c}{ Environmental Impact } & Impact Score & \multicolumn{1}{c}{ Unit } \\
\hline Acidification potential * $^{*}$ & 8.424 & $\mathrm{~kg} \mathrm{SO}_{2}$-equiv \\
Eutrophication potential $^{* *}$ & 1.048 & $\mathrm{~kg} \mathrm{PO}_{43}$-equiv \\
Freshwater aquatic Eco-toxicity potential $^{* *}$ & 5849.6 & $\mathrm{~kg} \mathrm{DCB}$-equiv \\
Terrestrial Eco-toxicity potential $^{* *}$ & 7.122 & $\mathrm{~kg} \mathrm{DCB}$-equiv \\
\hline
\end{tabular}

Source [47] (Ntiamoah and Afrane 2008). ${ }^{*}$ These effects are almost exclusive to the processing stage (about 97\%)

** These effects are almost exclusive to the production stage, mainly due to fertilizer and pesticide use ( $>96 \%)$.

The eutrophication effect was found to be almost exclusively attributable to the production stage and almost negligible for the processing phase. Similarly, the freshwater aquatic and terrestrial toxicity were almost exclusively attributable to the cocoa production stage. Acidification, on the other hand, was an indication of the gradual degradation of the soil, and it was caused by the acid solution formed when pollutants were released into the atmosphere. For the acidification potential, the impact was found to be almost exclusively attributable to the processing stage (about $97 \%$ ), while the production stage only accounted for the remaining $3 \%$ [47].

In addition, [47] the estimated quantity of pesticides residue and heavy metals that infiltrated freshwater and soils through runoff or leaching is shown in Table 8. Approximately $3.7 \mathrm{~kg}$ and $0.95 \mathrm{~kg}$ of pesticides were released to freshwater and soils, respectively, during the production of one tonne of cocoa beans in Ghana. Similarly, about $0.042 \mathrm{~kg}$ of heavy metals were released to the agricultural soils in the production of one tonne of cocoa beans in Ghana. 
Table 8. Pesticides emissions to freshwater and soil during the production of cocoa beans in Ghana (1 tonne of cocoa beans).

\begin{tabular}{lrr}
\hline \multicolumn{1}{c}{ Emissions } & Quantity (kg per Tonne of Cocoa Beans) & Reference \\
\hline Pesticides to freshwater & 3.69 & \\
Pesticides to soil & 0.945 & [47] \\
Heavy metals to agricultural soil & 0.042 & \\
\hline
\end{tabular}

\subsubsection{Pesticides Effect on Human Health}

The pathways through which pesticides applied to cocoa farms may affect human health include: (1) through pesticide residues contaminating drinking water sources, (2) through traces of pesticides left in cocoa beans and, (3) through the physical contact with pesticides during the process of pesticide application. The cocoa bean has a high content of butter or fat, which can absorb the active ingredients found in insecticides [48]. Thus, [49] assessed the levels of pesticide residues in fermented, dried cocoa beans to find out whether the pesticides residue levels in Ghana's cocoa beans were a public health concern. They found that the levels of organochlorine pesticide residues in the fermented, dried cocoa beans analyzed compared favourably to the European Union (EU) commission regulations on pesticide residues and showed no health risks to consumers of cocoa beans from Ghana and no threat to cocoa exports to Europe.

Similarly, several studies assessed the levels of pesticide residues in soils and drinking water sources from cocoa farms in Ghana, e.g., [43,44,46,49], to determine whether they were a health hazard. For these studies, although most of the pesticide residues recorded in the water were below the WHO MRLs for drinking water, certain pesticides exceeded the WHO MRLs at some sampled sites. Therefore, this suggested that the pesticide residue concentrations in some of the wells from which the samples were obtained for this study could pose health hazards to farmers households and their entire communities, who utilized water from these same sources.

However, most of the direct health effects of pesticides were linked to the process of pesticide application by the cocoa farmers who did not wear protective gear. For example, a study by [46] assessed the health effects among cocoa farmers in Ghana. The study found that almost all the farmers interviewed experienced health-related issues during and after pesticide application. The reported health effects were presented in Table 9; the majority of the farmers reported cases of watery eyes $(83 \%)$, headaches $(74 \%)$, dizziness $(55 \%)$, chest pains $(42 \%)$, coughing $(32 \%)$ and skin irritation $(30 \%)$ during and after applying pesticides to the cocoa farms. Other less common health conditions that were reported included nausea, body weakness, burning eyes, itchy eyes and excessive sweating.

Table 9. Health costs related to pesticides application by the cocoa farmers.

\begin{tabular}{lllll}
\hline Health-Related Issue & $\begin{array}{l}\text { Probability a Person } \\
\text { will be Infected }\end{array}$ & Treatment (Drug Class) & $\begin{array}{l}\text { Average Cost of One } \\
\text { Dosage (USD) }\end{array}$ & $\begin{array}{l}\text { Treatment Cost per } \\
\text { Person (USD) }\end{array}$ \\
\hline Watery eyes & 0.83 & Antibiotics & 10 & 8.3 \\
Headaches & 0.74 & Pain killers (aspirin) & 2 & 1.48 \\
Dizziness & 0.55 & Antiemetics & 11 & 6.05 \\
Chest pains & 0.42 & Corticosteroids for asthma & 18 & 7.56 \\
Cough & 0.317 & and allergies & 10 & 3.17 \\
Skin irritation & 0.3 & Opiods & 18 & 5.4 \\
Itchy eyes & 0.25 & Corticosteroids & 32 & 1.76 \\
Nausea & 0.22 & Antihistamines & 8 & 6.944 \\
Burning eyes & 0.217 & Antihistamines & 32 & 1.71 \\
Excessive sweating & 0.171 & Antihistamines & 10 & 0 \\
Weakness & 0.154 & Antiperspirants & 13 & 0.702 \\
Fever & 0.054 & Ibuprofen & & 51.08 \\
Total treatment cost per person per dosage (USD) & & & \\
\hline
\end{tabular}


To estimate the health costs related to pesticide use by the cocoa farmers of Ghana, we used the treatment cost as a proxy. Table 9 presents the estimates of the cost of treating different ailments reported by farmers who applied pesticides on cocoa farms without protective gear. The majority of the farmers treated these illnesses with over-the-counter prescriptions; hence, we applied the approximate costs of these prescriptions. For data on the valuation of health costs using the treatment cost (cost-of-illness) approach, the search for treatment drugs and their respective costs was not restricted to any specific region. The total treatment cost per person was estimated as follows:

$$
\text { Ttc }=\sum \text { Ac xprob affected }
$$

where: Ttc $=$ the total treatment cost per person per dosage.

$A c=$ the average cost of treatment per person per dosage.

prob affected $=$ the probability that a random person in the area will be infected with a specific illness.

However, this was a minimum estimate of the cost of impacts as it still did not capture all the costs related to pesticides application, including hospital visits, if any, labour days lost due to the sickness or a potentially shortened lifespan. Therefore, there is a need for a more detailed study to capture all the health costs related to pesticides application, possibly by estimating the disability-adjusted life years (DALYs) and quality-adjusted life-years (QALYs).

Further still, $[47,48]$ applied the life cycle assessment (LCA) approach in an effort to capture the environmental and health effects associated with the production and processing of cocoa in Ghana, as well as the effects of the pesticides in the cocoa food chain in Ghana. These studies reported the health impact, in terms of human toxicity potential (HTP), for the production and processing of $1 \mathrm{~kg}$ of cocoa beans in Ghana, as shown in Table 8 . The HTP is a measure of human toxicity and, for both studies, human toxicity was the most significant in terms of magnitude compared to the other measures of environmental impacts, eutrophication, freshwater aquatic and terrestrial toxicity. The reported levels of HTP were almost exclusive to the cocoa production stage $(>96 \%)$, while the processing stage contributed only a small proportion $[47,48]$. The high human toxicity levels can, therefore, be attributed to fertilizer and pesticide use during cocoa production.

\subsubsection{Greenhouse Gases Emissions}

The bulk of the greenhouse gas (GHG) emissions in the chocolate/cocoa value chain occurred at the production stage, attributable to fertilizer and pesticide use [47,50]. Some studies estimated the total GHGs for the entire chocolate value chain to be $3.36-3.6 \mathrm{~kg}$ CO2e per $\mathrm{kg}$ of chocolate [50,51]. Applying the LCA approach, [47] estimated the GHG emissions from cocoa production to be $0.323 \mathrm{~kg}$ CO2e per $\mathrm{kg}$ of cocoa beans produced.

\section{Discussion and Policy}

Based on a comprehensive literature search, we analysed the trade-offs that existed among different cocoa production systems in Ghana: shaded (agroforestry), full-sun and high-tech cocoa systems. Although cocoa yields were lower in agroforestry systems, the total provisioning services were highest in the agroforestry system. This was because agroforestry systems provided multiple streams of income, including timber and plantain, among others. Similarly, we found that agroforestry systems provided many ecosystem services, mainly carbon sequestration, maintaining biodiversity and biological disease control compared to cocoa monocultures. Compared to other production systems, hightech cocoa systems used significantly more inputs, fertilizers and pesticides. High pesticide use in cocoa production was linked to negative effects on water, soils and human health. Hence, there was a need for policies and practices that promoted positive ecosystem services and discouraged negative externalities in cocoa production. We discussed some of these policies and practices. 


\subsection{Certification Programs as Incentives for Sustainable Cocoa Production}

Concerns over the environmental impact of cocoa farming and its sustainability in Ghana have been raised in recent times. Major sustainability standards active in the global cocoa sector include Organic, Fairtrade, UTZ Certified and the Rainforest Alliance [52]. Organic focuses on a healthy planet, ecology and care for future generations; Fairtrade emphasizes farmer empowerment, social development and long-term business relationships; the Rainforest Alliance concentrates on biodiversity conservation, and UTZ-Certified produce focuses on sustainable agricultural practices and sourcing. However, all four sustainability standards promised better incomes for producers and prohibited child labour in order to improve both producer and child welfare [53].

However, most cocoa certifications and other sustainability initiatives mainly focus on social issues (e.g., child labour), as the environmental aspects are not yet clear to consumers [54]. Nonetheless, climate change awareness is changing. For example, the Rainforest Alliance aims to promote environmentally sustainable cocoa production. To become certified, the Rainforest Alliance dictates that farmers adhere to the production and social standards promulgated by the Sustainable Agriculture Network [8]. The Rainforest Alliance has specific requirements for farmers to maintain existing shade trees or plant new ones. The producer benefits of certification depend on: (1) the extent to which consumers are willing to pay premiums for process attributes, such as child labour-free or shade-grown cocoa; (2) the efficiency of market actors to adapt to the demands of differentiated markets; and (3) the productivity of the proposed system [8].

According to [8], the Rainforest Alliance Certified cocoa farmers in Ghana were paid a premium of GHS 72 (approximately USD 15.25) per tonne of cocoa. Different studies argue that the amount of certification premium paid to farmers is insufficient to make the agroforestry cocoa systems as profitable as the full-sun cocoa systems. For example, [8] argues that, even with a premium of USD 40 per tonne, the profitability of the Rainforest Alliance-certified cocoa agroforestry systems will still be less than that of an intensive monoculture, owing to the higher cocoa productivity within the intensive system.

\subsection{Agroforestry as a Potential for Climate Change Mitigation and REDD+}

Compared to cocoa monocultures, cocoa agroforestry systems have greater potential for climate change mitigation due to a higher carbon sequestration potential $[38,55]$. Carbon payments are a potential incentive for farmers to plant trees. However, systems directing these payments to cocoa producers are rarely found, and the payments tend to be too low to incentivize the planting of shade trees [13].

Agroforestry offers the potential for REDD+ (reducing emissions from deforestation and forest degradation). Given the ecological role of agroforestry systems in carbon sequestration, improved biodiversity and soil nutrition, such systems could potentially be an interesting climate change mitigation option under the United Nations Framework Convention on Climate Change (UNFCCC). Cocoa agroforestry systems would provide opportunities to engage millions of smallholder farmers in REDD+ schemes with cobenefits, such as climate change adaptation, mitigation, and the restoration of degraded landscapes [56]. Depending on how a country defines what constitutes a forest, there are several options for relating agroforestry to the REDD+ activities [6]. For Ghana, UNFCCC defines a forest as having a minimum of $15 \%$ tree cover, at least 1 ha of area and a tree height of 5 metres. Based on these countries' definitions, agroforestry is not by default excluded from being officially regarded as a 'forest'. Rather, it depends on the size of the land, the extent of tree cover and the tree height. For example, looking at cocoa agroforestry systems in Ghana, they meet both countries' definitions of a forest. In contrast, full-sun/cocoa plantations often do not meet the forest definitions due to the minimum tree height criterion [56].

There are already efforts to integrate REDD+ into Ghanan cocoa production. In 2008 Ghana adopted the REDD+ program to foster carbon goals [57]. The REDD+ program reinforces the conservation, sustainable management of forests and the enhancement of 
forest carbon stocks. The potential benefits envisaged include conservation of biodiversity, water and soil regulation, and direct human benefits, including enhancing opportunities for participatory natural resource management. The integration of cocoa agroforestry within REDD+ through the Cocoa Forest REDD+ program aims to improve net carbon gains through the integration of trees on croplands and subsequently provide an opportunity toward climate change mitigation [58].

\subsection{Regulations for Pesticide Use, a Solution?}

Pesticide use in cocoa production in Ghana also creates huge environmental and health costs. Health costs are mainly due to pesticide application since the majority of farmers do not use protective gear while applying pesticides. The environmental costs are also attributable to the pesticide residues in the soils and water bodies. Cocoa processing is also found to cause soil degradation through the acidification process from the pollutants released into the air. Ghana has implemented policies that promote the safe use of pesticides and discourage the use of organochlorines. Therefore, there is a need to strengthen the enforcement of these policies, as well as offer regular training to the farmers on the safe handling of pesticides.

\subsection{Collective Action in Promoting Sustainable Cocoa Production}

An example of collective action within the cocoa sector is CocoaAction, the largest platform in the cocoa sector for dealing with sustainable development. It was initiated in 2014 by the World Cocoa Foundation (WCF) to bring all the major cocoa processors and chocolate manufacturers together to build an economically viable and sustainable supply chain. The World Cocoa Foundation, consisting of 100 member companies representing $80 \%$ of the global corporate market, is the convener and strategy holder of CocoaAction [59]. CocoaAction companies have also partnered with the governments of Ghana and Cote $\mathrm{d}^{\prime}$ Ivoire, as well as key stakeholders on formal agreements to ensure that the cocoa supplied to the companies is sustainably produced $[59,60]$. Such initiatives have played a role in promoting sustainable cocoa production in Ghana and Cote d'Ivoire, which are the leading cocoa-producing countries globally.

\section{Conclusions}

Cocoa remains an essential tree commodity in Africa, particularly in Ghana, which is the second-largest producer of cocoa worldwide. This study analysed the trade-offs among shaded, full-sun and high-tech cocoa production systems from an economic and ecosystem services approach. There were trade-offs between cocoa yields and other provisioning services among the different cocoa production systems in Ghana. While cocoa yield was higher in full-sun cocoa systems, the total provisioning services were highest in agroforestry cocoa systems. In addition, there were ecosystem services within the cocoa agroforestry systems, including carbon sequestration, maintaining biodiversity, soil fertility, pollination, and biological pest and disease control.

Some of the established ecosystem services provided by these systems included carbon sequestration, enhanced soil fertility, biodiversity conservation, and biological pest and disease control and pollination, while the development of local, national, and global economy was the main economic benefit associated with the systems development. However, there were also several notable negative externalities related to the use of inputs such as fertilizers, agrochemicals, and pesticides, which were highly used in intensive high-tech production systems. These chemical inputs negatively affected water, soil and air quality, in addition to causing biodiversity loss and human health complications. Similarly, greenhouse gases were emitted throughout the cocoa value chain, but the production stage captured the bulk of the GHGs resulting from fertilizer and pesticide use. As such, it was crucial to strike a balance between the benefits and trade-offs associated with cocoa production systems. Notably, cocoa development systems were largely contextualized, with people, policies, institutions and larger ecosystems playing the central role. 
Effective policies and institutional arrangements are crucial for the successful development of these systems and for reducing the associated trade-offs. For example, a clear regulatory framework on the types of agrochemicals that are less harmful to the environment and human health can contribute greatly to the success of cocoa systems. This may require increased multisectoral engagements and a multi-stakeholder involvement to strengthen the prevailing policies and institutions guiding cocoa system development at different scales in order to reduce the established trade-offs and interests of different stakeholders. The issues around labour, gender inequalities and ecological resiliency are equally essential when developing sustainable cocoa production systems from policy and institutional perspectives.

Author Contributions: Conceptualization, P.W., P.A.M., L.D.; formal analysis, P.W.; writing—original draft preparation, P.W., K.M.; funding acquisition; P.A.M., L.D.; writing-review and editing, P.W., P.A.M., L.D. and K.M.; supervision P.A.M. All authors have read and agreed to the published version of the manuscript.

Funding: This research was funded by the Forests, Trees and Agroforestry (FTA) Research Program of the CGIAR, Grant Number FP 4 and FP 5 and UNEP TEEB (The Economics of Ecosystems and Biodiversity) small-scale funding agreement (SSFA) grant.

Institutional Review Board Statement: Not applicable.

Informed Consent Statement: Not applicable.

Acknowledgments: The underlying research was carried out as part of the UN Environment (UNEP) TEEB (The Economics of Ecosystems and Biodiversity) small-scale funding agreement (SSFA) grant, and Forests, Trees and Agroforestry (FTA) Research Program of the CGIAR, specifically Flagship 4 and 5 . We are grateful for the inputs we received from the UNEP TEEB team.

Conflicts of Interest: The authors declare no conflict of interest.

\section{References}

1. Waarts, Y.R.; Janssen, V.; Ingram, V.J.; Slingerland, M.A.; van Rijn, F.C.; Beekman, G.; Dengerink, J.; van Vliet, J.A.; Arets, E.J.M.M.; Sassen, M.; et al. A Living Income for Smallholder Commodity Farmers and Protected Forests and Biodiversity: How Can the Private and Public Sectors Contribute?: White Paper on Sustainable Commodity Production; (No. 2019-122); Wageningen Economic Research: Wageningen, The Netherlands, 2019.

2. Asare, R.; Afari-Sefa, V.; Osei-Owusu, Y.; Pabi, O. Cocoa agroforestry for increasing forest connectivity in a fragmented landscape in Ghana. Agrofor. Syst. 2014, 88, 1143-1156. [CrossRef]

3. Asare, R. A review on cocoa agroforestry as a means for biodiversity conservation. In Proceedings of the World Cocoa Foundation Partnership Conference, Brussels, Belgium, May 2006; Volume 15.

4. Ruf, F.; Schroth, G. Chocolate forests and monocultures: A historical review of cocoa growing and its conflicting role in tropical deforestation and forest conservation. In Agroforestry and Biodiversity Conservation in Tropical Landscapes; Island Press: Washington, DC, USA, 2004; pp. 107-134.

5. Vaast, P.; Somarriba, E. Trade-offs between crop intensification and ecosystem services: The role of agroforestry in cocoa cultivation. Agrofor. Ssyst. 2014, 88, 947-956. [CrossRef]

6. Minang, P.A.; Duguma, L.A.; Bernard, F.; Mertz, O.; van Noordwijk, M. Prospects for agroforestry in REDD+ landscapes in Africa. Curr. Opin. Environ. Sustain. 2014, 6, 78-82. [CrossRef]

7. Ruf, F.O. The myth of complex cocoa agroforests: The case of Ghana. Hum. Ecol. 2011, 39, 373-388. [CrossRef]

8. Gockowski, J.; Afari-Sefa, V.; Sarpong, D.B.; Osei-Asare, Y.B.; Agyeman, N.F. Improving the productivity and income of Ghanaian cocoa farmers while maintaining environmental services: What role for certification? Int. J. Agric. Sustain. 2013, 11, 331-346. [CrossRef]

9. Byerlee, D.; Stevenson, J.; Villoria, N. Does intensification slow crop land expansion or encourage deforestation? Glob. Food Sec. 2014, 3, 92-98. [CrossRef]

10. Ngoma, H.; Angelsen, A. Can conservation agriculture save tropical forests? The case of minimum tillage in Zambia. For. Policy Econ. 2018, 97, 153-162. [CrossRef]

11. Muthee, K.; Duguma, L.; Nzyoka, J.; Minang, P. Ecosystem-based adaptation practices as a nature-based solution to promote water-energy-food nexus balance. Sustainability 2021, 13, 1142. [CrossRef]

12. Chiputwa, B.; Ihli, H.J.; Wainaina, P.; Gassner, A. Accounting for the invisible value of trees on farms through valuation of ecosystem services. In The Role of Ecosystem Services in Sustainable Food Systems; Academic Press: Cambridge, MA, USA, 2020; pp. 229-261. 
13. Niether, W.; Jacobi, J.; Blaser, W.J.; Andres, C.; Armengot, L. Cocoa agroforestry systems versus monocultures: A multidimensional meta-analysis. Environ. Res. Lett. 2020, 15, 104085. [CrossRef]

14. Tschora, H.; Cherubini, F. Co-benefits and trade-offs of agroforestry for climate change mitigation and other sustainability goals in West Africa. Glob. Ecol. Conserv. 2020, 22, e00919. [CrossRef]

15. Wessel, M.; Quist-Wessel, P.F. Cocoa production in West Africa, a review and analysis of recent developments. NJAS-Wagening. J. Life Sci. 2015, 74, 1-7. [CrossRef]

16. Läderach, P.; Martinez-Valle, A.; Schroth, G.; Castro, N. Predicting the future climatic suitability for cocoa farming of the world's leading producer countries, Ghana and Côte d'Ivoire. Clim. Change 2013, 119, 841-854. [CrossRef]

17. Gockowski, J.; Sonwa, D. Cocoa intensification scenarios and their predicted impact on $\mathrm{CO}_{2}$ emissions, biodiversity conservation, and rural livelihoods in the Guinea rain forest of West Africa. Environ. Manag. 2011, 48, 307-321. [CrossRef]

18. Alemagi, D.; Minang, P.A.; Duguma, L.A.; Kehbila, A.; Ngum, F. Pathways for sustainable intensification and diversification of cocoa agroforestry landscapes in Cameroon. In Climate-Smart Landscapes: Multifunctionality in Practice; Minang, P.A., van Noordwijk, M., Freeman, O.E., Mbow, C., de Leeuw, J., Catacutan, D., Eds.; World Agroforestry Centre (ICRAF): Nairobi, Kenya, 2015; pp. 347-359.

19. Gockowski, J.; Afari-Sefa, V.; Sarpong, D.B.; Osei-Asare, Y.B.; Dziwornu, A.K. Increasing income of Ghanaian cocoa farmers: Is introduction of fine flavour cocoa a viable alternative. Q. J. Int. Agric. 2011, 50, 175-200.

20. Abdulai, I.; Jassogne, L.; Graefe, S.; Asare, R.; Van Asten, P.; Läderach, P.; Vaast, P. Characterization of cocoa production, income diversification and shade tree management along a climate gradient in Ghana. PLoS ONE 2018, 13, e0195777. [CrossRef] [PubMed]

21. Wade, A.S.; Asase, A.; Hadley, P.; Mason, J.; Ofori-Frimpong, K.; Preece, D.; Spring, N.; Norris, K. Management strategies for maximizing carbon storage and tree species diversity in cocoa-growing landscapes. Agric. Ecosyst. Environ. 2010, 138, 324-334. [CrossRef]

22. Foundjem-Tita, D.; Degrande, A.; Donovan, J.; Stoian, D.; Kouamé, C. Baseline for Assessing the Impact of Fairtrade Certification on Cocoa Farmers and Cooperatives in Côte d'Ivoire; World Agroforestry Centre: Nairobi, Kenya, 2017.

23. Namirembe, S.; McFatridge, S.; Duguma, L.; Bernard, F.; Minang, P.; Sassen, M.; van Soersbergen, A.; Eyerusalem, A. Agroforestry: An Attractive REDD+ Policy Option; World Agroforestry Centre (ICRAF): Nairobi, Kenya, 2015.

24. Obiri, B.D.; Bright, G.A.; McDonald, M.A.; Anglaaere, L.C.; Cobbina, J. Financial analysis of shaded cocoa in Ghana. Agrofor. Syst. 2007, 71, 139-149. [CrossRef]

25. Nunoo, I.; Owusu, V.; Darko Obiri, B. Cocoa agroforestry a bridge for sustainable organic cocoa production. Build. Org. Bridges 2014, 2, 555-558.

26. Owusu-Amankwah, R. Certifications, Child Labour and Livelihood Strategies: An Analysis of Cocoa Production in Ghana. Ph.D. Thesis, Wageningen University, Wageningen, The Netherlands, 2015.

27. MoFA Ministry of Food and Agriculture. Agriculture in Ghana; Facts and Figures (2015); Ministry of Food and Agriculture Statistics, Research and Information Directorate (Srid): Accra, Ghana, 2016.

28. Jose, S. Agroforestry for conserving and enhancing biodiversity. Agrofor. Syst. 2012, 85, 1-8. [CrossRef]

29. Asase, A.; Wade, S.A.; Ofori-Frimpong, K.; Hadley, P.; Norris, K. Carbon storage and the health of cocoa agroforestry ecosystems in south-eastern Ghana. Afr. Carbon Cycle 2008, 131.

30. Acheampong, E.; Dawoe, E.; Bosu, P.; Asante, W. Moving Forward with REDD+ in Ghana: Shade Systems, Crown Cover, Carbon Stocks and Socio-Economic Dynamics of Smallholder Cocoa Agroforestry Systems; REDD+ Energy and Agriculture Programme, SNV World: Accra, Ghana, 2014.

31. Holbech, L.H. The conservation importance of luxuriant tree plantations for lower storey forest birds in south-west Ghana. Bird Conserv. Int. 2009, 19, 287-308. [CrossRef]

32. Anglaaere, L.C.; Cobbina, J.; Sinclair, F.L.; McDonald, M.A. The effect of land use systems on tree diversity: Farmer preference and species composition of cocoa-based agroecosystems in Ghana. Agrofor. Syst. 2011, 81, 249-265. [CrossRef]

33. Blaser, W.J.; Oppong, J.; Hart, S.P.; Landolt, J.; Yeboah, E.; Six, J. Climate-smart sustainable agriculture in low-to-intermediate shade agroforests. Nat. Sustain. 2018, 1, 234-239. [CrossRef]

34. Mohammed, A.M.; Robinson, J.S.; Midmore, D.; Verhoef, A. Carbon storage in Ghanaian cocoa ecosystems. Carbon Balance Manag. 2016, 11, 6. [CrossRef] [PubMed]

35. Dawoe, E.; Asante, W.; Acheampong, E.; Bosu, P. Shade tree diversity and above-ground carbon stocks in Theobroma cacao agroforestry systems: Implications for REDD+ implementation in a West African cacao landscape. Carbon Balance Manag. 2016, 11, 17. [CrossRef] [PubMed]

36. Dawoe, E.K.; Quashie-Sam, J.S.; Oppong, S.K. Effect of land-use conversion from forest to cocoa agroforest on soil characteristics and quality of a Ferric Lixisol in lowland humid Ghana. Agrofor. Syst. 2014, 88, 87-99. [CrossRef]

37. Dawoe, E.K.; Isaac, M.E.; Quashie-Sam, J. Litterfall and litter nutrient dynamics under cocoa ecosystems in lowland humid Ghana. Plant Soil. 2010, 330, 55-64. [CrossRef]

38. Blaser, W.J.; Oppong, J.; Yeboah, E.; Six, J. Shade trees have limited benefits for soil fertility in cocoa agroforests. Agric. Ecosyst. Environ. 2017, 243, 83-91. [CrossRef]

39. Andres, C.; Blaser, W.J.; Dzahini-Obiatey, H.K.; Ameyaw, G.A.; Domfeh, O.K.; Awiagah, M.A.; Gattinger, A.; Schneider, M.; Offei, S.K.; Six, J. Agroforestry systems can mitigate the severity of cocoa swollen shoot virus disease. Agric. Ecosyst. Environ. 2018, 252, 83-92. [CrossRef] 
40. Maas, B.; Clough, Y.; Tscharntke, T. Bats and birds increase crop yield in tropical agroforestry landscapes. Ecol. Lett. 2013, 16, 1480-1487. [CrossRef]

41. Claus, G.; Vanhove, W.; Van Damme, P.; Smagghe, G. Challenges in cocoa pollination: The case of Côte d'Ivoire. Pollinat. Plants 2018, 39. [CrossRef]

42. Frimpong, E.A.; Gemmill-Herren, B.; Gordon, I.; Kwapong, P.K. Dynamics of insect pollinators as influenced by cocoa production systems in Ghana. J. Pollinat. Ecol. 2011, 5, 74-80.

43. Fosu-Mensah, B.Y.; Okoffo, E.D.; Darko, G.; Gordon, C. Organophosphorus pesticide residues in soils and drinking water sources from cocoa producing areas in Ghana. Environ. Syst. Res. 2016, 5, 10. [CrossRef]

44. Fosu-Mensah, B.Y.; Okoffo, E.D.; Darko, G.; Gordon, C. Assessment of organochlorine pesticide residues in soils and drinking water sources from cocoa farms in Ghana. SpringerPlus 2016, 5, 869. [CrossRef]

45. Okoffo, E.D.; Mensah, M.; Fosu-Mensah, B.Y. Pesticides exposure and the use of personal protective equipment by cocoa farmers in Ghana. Environ. Syst. Res. 2016, 5, 17. [CrossRef]

46. Okoffo, E.D. Pesticide Use and Pesticide Residues in Drinking Water, Soil and Cocoa Beans in the Dormaa West District of Ghana. Ph.D. Thesis, University of Ghana, Accra, Ghana, 2015.

47. Ntiamoah, A.; Afrane, G. Environmental impacts of cocoa production and processing in Ghana: Life cycle assessment approach. J. Clean. Prod. 2008, 16, 1735-1740. [CrossRef]

48. Afrane, G.; Ntiamoah, A. Use of pesticides in the cocoa industry and their impact on the environment and the food chain. Pestic. Mod. World-Risks Benefits InTech 2011, 51-68.

49. Okoffo, E.D.; Fosu-Mensah, B.Y.; Gordon, C. Persistent organochlorine pesticide residues in cocoa beans from Ghana, a concern for public health. Int. J. Food Contam. 2016, 3, 5. [CrossRef]

50. Konstantas, A.; Jeswani, H.K.; Stamford, L.; Azapagic, A. Environmental impacts of chocolate production and consumption in the UK. Food Res. Int. 2018, 106, 1012-1025. [CrossRef]

51. Büsser, S.; Jungbluth, N. LCA of Chocolate Packed in Aluminium Foil Based Packaging. ESU-Services Ltd. Uster, Switzerland; Commissioned by German Aluminium Association (GDA) in cooperation with European Aluminium Foil Association (EAFA): Düsseldorf, Germany, 2009.

52. Potts, J.; Lynch, M.; Wilkings, A.; Huppé, G.A.; Cunningham, M.; Voora, V.A. The State of Sustainability Initiatives Review 2014: Standards and the Green Economy; International Institute for Sustainable Development: Winnipeg, MB, Canada, 2014.

53. Akoyi, K.T.; Mitiku, F. Private Sustainability Standards as Market-Based Tools for Mainstreaming Climate Smart Agriculture; KU Leuve: Heverlee, Belgium, 2018.

54. Camargo, M.; Nhantumbo, I. Towards Sustainable Chocolate: Greening the Cocoa Supply Chain; IIED: London, UK, 2016.

55. Wainaina, P.; Minang, P.; Duguma, L. Application of the TEEB for Agriculture and Food (TEEBAgriFood) Framework: Case of Cocoa and Coffee Agroforestry Value Chains in Ghana and Ethiopia; UNEP TEEB: Nairobi, Kenya, 2020.

56. Minang, P.A.; Duguma, L.A. Agroforestry: A Potential REDD+ Policy Measure in Coffee and Cocoa Systems; UN-REDD Policy Brief No. 8: Nairobi, Kenya, 2017.

57. Asare, A.R.; Kwakye, Y. A Guide to Implementing REDD+ in Ghana: Criteria and Modalities for Developing a REDD+ Project. 2013. Available online: http://www.itto.int/files/itto_project_db_input/3046/Technical/RED-PD093-12Rev.3(F)_ProgressReport\%2031-Jan-2014\%20Annex1-Guide-Implementing-REDD-Ghana.pdf (accessed on 15 August 2021).

58. Ameyaw, L.K.; Ettl, G.J.; Leissle, K.; Anim-Kwapong, G.J. Cocoa and climate change: Insights from smallholder cocoa producers in Ghana regarding challenges in implementing climate change mitigation strategies. Forests 2018, 9, 742. [CrossRef]

59. World Cocoa Foundation. Establishing Our Roots: Preparing to Grow, CocoaAction Annual Report 2015. Available online: https:/ / www.worldcocoafoundation.org/wp-content/uploads/CocoaAction-Annual-Report-2015-English.pdf (accessed on 18 June 2021).

60. Odijie, M.E. Sustainability winners and losers in business-biased cocoa sustainability programmes in West Africa. Int. J. Agric. Sustain. 2018, 16, 214-227. [CrossRef] 